\title{
Impact of Workplace Conflict Management on Organizational Performance: A Case of Nigerian Manufacturing Firm
}

\author{
Olukayode Longe ${ }^{1}$ \\ ${ }^{1}$ Department of Sociology, Faculty of the Social Sciences, Ekiti State University, Ado-Ekiti, Nigeria \\ Correspondence: Olukayode Longe, Department of Sociology, Faculty of the Social Sciences, Ekiti State University, \\ Ado-Ekiti, Ado-Ekiti, Ekiti State, Nigeria. E-mail: premiumkay@gmail.com
}

Received: January 24, 2015

Accepted: February 25, 2015

Online Published: May 14, 2015

doi:10.5430/jms.v6n2p83

URL: http://dx.doi.org/10.5430/jms.v6n2p83

\begin{abstract}
This study investigated the impact of workplace conflict management on organizational performance in a Nigerian manufacturing firm. Participants comprised 250 employees selected through the use of stratified random sampling technique. Data were generated through the use of validated structured questionnaire. Descriptive and inferential statistics were employed to analyze data collected from the respondents. Employing Spearman correlation analysis, the results of the empirical tests showed a significantly positive relationship between conflict management strategies (collective bargaining, compromise, and accommodation) and organizational performance. Non-integrative conflict management strategies (competition, domination and avoidance) had a negative statistically determinate effect on organizational performance. Also, the result of the regression analysis indicated that collective bargaining strategy displayed the highest significant positive correlation with organizational performance. In addition, study findings revealed that conflicts arose over multiple factors of organizational experiences based on economic and goal incompatibility orientations in the workplace. Union-management conflict was discovered as the most prevalent type of industrial conflict in the organization. The study concluded that conflict was an unavoidable phenomenon in organizational life and it could contribute to or detract from organizational performance depending on the conflict management methods adopted in the workplace.
\end{abstract}

Keywords: conflict management, organization, organizational performance and workplace conflict

\section{Introduction}

The structurally differentiated character of contemporary work-organizations, whether in the manufacturing or service industry inevitably generates conflicts of interest. These conflicts of interests arise in groups because of the scarcity of freedom, position and resources (Hotepo, Asokere, Abdul-Azeez and Ajemunigbohun, 2010). Workplace conflict is thus endemic despite the best of management practices in organizations and manifests in various forms as an intrinsic and unavoidable feature of employment relationship. It is by nature an ever present process and more likely to occur in hierarchical organizations where people with divergent view, opinion and background interact. However, conflict in work-relations is not an aberration, since it creates or provides an opportunity for correction and reconciliation for the betterment of both the organization and the workers (Osad and Osas, 2013).

According to Kazimoto (2013), workplace conflict is described as the presence of discord that occurs when goals, interests or values of different individuals or groups are incompatible and frustrate each others' attempt to achieve objectives in an organization. It is a communication process and an inevitable consequence of transactional relationship manifesting in disagreement and dissonance with and between individuals and groups in the work-environment. In this context, workplace conflict is a fact of life in any organization as long as people will compete for jobs, power, recognition and security (Adomie and Anie, 2005). Therefore, the task of management is not to suppress or resolve all conflicts, but to manage them in order to enhance and not to detract from organizational performance.

Akanji (2005) opined that constructively managed conflict induces a positive performance, while destructively managed conflict heats up the work environment to bring about dislocation and polarization of the entire group with reduction in productivity and job performance. This is suggestive that a well-managed conflict aims at the improvement of organizations for the purpose of stimulating performance in the work-situation. Through good conflict management strategies, weaknesses in the organizational decision-making are exposed which may prompt 
the establishment to effect changes and search for positive solutions. Hence, management are duty bound to resolve conflict properly for the sake of increasing organizational performance, because the outcome of such action will result in good communication, time management, good cooperation and increase corporate productivity (Obasan, 2011).

With the permanent nature of conflict in work-relations, high performance organizations will be those that may constantly develop the appropriate methods of managing conflict to achieve set-standards and goals. As is now established, the Nigerian organizations have for a long time been concerned with the effect of conflict management on business performance in the country. However, empirical validation of findings across industries is very limited at best. The available few studies within the country have concentrated mainly on service and construction industries. Empirical research efforts are still passive in focusing on the manufacturing industries. As such, this present study is an attempt to redress the situation by providing valuable insights to management in the manufacturing organizations about the strategic importance of conflict management as a resource tool for optimizing business performance. Thus, the broad objective of this empirical study is to explore the impact of workplace conflict management on organizational performance in a manufacturing firm in Nigeria. From this general aim, the study also seeks the following specific objectives, which are to:

i. identify the causative factors of conflict in the manufacturing organization,

ii. examine the types of conflict that are prevalent in the establishment,

iii. access the conflict management strategies adopted for use in the organization and

iv. determine the effect of workplace conflict management on organizational performance in the establishment.

\section{Literature Review}

\subsection{Concept of Workplace Conflict}

Workplace conflict has been defined in several ways by many authors. Obi (2012) defined workplace conflict as an act of discontentment and contention which either the workers or employers of labour utilize to put excessive pressure against each other so as to get their demands. This view is consistent with Henry (2009); Ikeda, Veludo and Campomar (2005); Azamoza (2004) and Ajala and Oghenekohwo (2002) descriptions of workplace conflict as a dispute that occurs when interests, goals or values of different individuals or groups are incompatible with each other in organizations. On this premise, workplace conflict within the context of employment relationship can be regarded as an inevitable clash of interests and resulting disputes of varying intensity between and within any or all of the active actors in organizations. Thus, in the absence of common values in organizations, conflict is bound to occur.

\subsection{Causative Factors of Work-place Conflict}

Empirical research findings have provided insights into causative factors of workplace conflict. Hotepo, Asokere, Abdul - Azeez and Ajemunigbohun (2010) found lack of resources, different expectation, competition, lack of cooperation, interdependence and communication problems as factors that have caused conflicts in the Nigerian service industry. Relatedly, in the banking sector in Nigeria, Obasan (2011) identified unacceptable terms of employment, poor human relations between management and workers, non - consultation with employees before making key decisions affecting them, anti-union posture of management and lack of effective mechanism for prevention of conflict as multiple causal factors of workplace conflict. A Philippian study also conducted in the banking industry by Tsevendorj (2008) rated communication failure, perception, values and culture problems as moderately serious sources of conflict. Thus, most organizational conflicts have economic and goal incompatibility orientations in the workplace.

\subsection{Classification of Workplace Conflict}

Ogunbameru (2006) classified workplace conflict into two broad types: informal and formal workplace conflicts. According to him, conflict in work-relations is informal when it is not based on any systematic organizational problem but results directly from a source of grievance and supposedly is wholly expressive in nature. In this connection, the underlying sources cannot be openly seen, but can be inferred from unconscious form of protest, sabotage, unruly behaviour and poor work-attitudes by employees in organizations. If the situation is sufficiently widespread, it can significantly affect employee job description focus, turnover and impact on the prosperity of an organization (Kazimoto, 2013). On the other hand, formal workplace conflict is referred to as an organized expression of conflict articulated through a trade union or other workers representatives (Ogunbameru, 2006). This type of conflict is highly visible, since it is often a conscious strategy or calculated attempt to obtain alteration in 
employment relationship. To sum all, Albert (2001) averred that there are two sides to workplace conflict, whether formal of informal, one is destructive and unhealthy and the other is productive and healthy, having a problem solving base. However, the two conflict situations are neither bad nor good, since disagreement and dissatisfaction must occur in work-relations for adjustment to be made to improve total workplace performance.

\subsection{Management of Workplace Conflict}

According to Rahim (2002) conflict management involves designing effective strategies to minimize the dysfunctions of conflict and enhance the constructive functions in order to optimize learning and effectiveness of an organization. This implies that managing conflict does not necessarily connote avoidance or termination but the decrease of the odds of non-productive escalation. As such, conflict management is the method by which organizations and people handle grievances or disputes so as to find a middle way alternative to increase resolution, work towards consensus and offer genuine commitment to decision-making. As observed by Uchendu, Anijaobi and Odigwe (2013), since conflict is inevitable in organizations, its management determines whether it will generate positive or negative effect on the organizational performance. The timely recognition and immediate explication of the underlying tension before the conflict issues go out of hand are germane to effectual management of conflict in the workplace.

Consequently, conflict management orientation is a highly obstrusive process which can be implemented in a number of diverse ways in organzations. Ford (2007) posited a four-way process which includes assessment and inquiry, design, implementation and evaluation aimed at achieving efficacious and objective conflict decision in the workplace. This integrative approach is often employed to encourage management to satisfy the needs of stakeholders in the resolution of conflict. Vigil and King (2000) observed that the use of integrative style of managing conflict is likely to create better result and higher commitment in individuals than teams using non-integrative conflict management. The integrative approach broadens the understanding of the conflict problem and increases resolution.

In the same vein, collective bargaining strategy has been suggested as the approach for managing union-management conflict in organizations. The approach is internationally acclaimed as the legal instrument by which workers and management settle conflicts arising from employment contracts (Fajana and Shadare, 2012). Presently, faster rates of adoption of collective bargaining strategies have been encouraged in Nigeria by the Trade Union Amendment Act (2000) and by the positive use of this machinery for resolving conflict by some multinational firms in the country. In practice, this collaborative approach of managing conflict, involves negotiation between union and management in a process of meeting demands, discussing, presenting counter demands, bluffing and sometimes threatening all in a bid to reach collective agreement.

Thomas (1976) also put forward some approaches for managing conflicts. These are avoidance, accommodation, competition, compromise and collaboration. The avoidance strategy is called conflict avoidance. Any organization using this method is sitting on a keg of gun-powder. The accommodation strategy believes that no amount of sacrifice is too much to allow peace to reign. It is a palliative technique which involves capitulation and appeasement. The competition strategy involves the survival of the fittest and win-lose method, without taking other party into consideration. In the compromise strategy, parties to the conflict are willing to give up something in order to settle the conflictual problem. The last approach is collaboration which is a win-win approach whereby parties to a conflict are prepared, willing and ready to satisfy each other demands fully. Except for the collaboration strategy which is reflected in behaviours that are both cooperative and assertive, all other approaches depend majorly on the structure of the organization, because they provide a short term solution to conflict situations.

Another conflict management approach for resolution of conflict in Nigeria is offered in the provision of the Trade disputes Amendment Decree, 1988, No. 39 and Trade dispute Act CAP 18, 2004 which provided five steps for legal management of conflict in organizations in the country. These are voluntary settlements of conflict using internal machinery of grievance procedures and the external machinery involving appointment of mediator, conciliator, reference of disputes to industrial arbitration panel, National Industrial Court and the constitution of a Board of Inquiry if such is considered necessary. In conflict resolution, the award of the National Industrial Court is final and binding on the employees and employers from the date of the award in the country.

\subsection{Research Hypotheses}

Based on the broad objective of the study and comprehensive review of the literature, the following hypotheses emerged.

$\mathrm{H}_{1}$ : There is a significant relationship between workplace conflict management and organizational performance. 
$\mathrm{H}_{2}$ : Collective bargaining strategy has significant relationship with organizational performance.

$\mathrm{H}_{3}$ : Compromise strategy has significant relationship with organizational performance

$\mathrm{H}_{4}$ : Accommodation strategy has significant relationship with organizational performance

$\mathrm{H}_{5}$ : Confrontation strategy has significant relationship with organizational performance

$\mathrm{H}_{6}$ : Competition strategy has significant relationship with organizational performance

$\mathrm{H}_{7}$ : Avoidance strategy has significant relationship with organizational performance

\section{Research Methods}

\subsection{Research Design, Population and Sampling Technique}

The study adopted a descriptive research design. The survey was conducted in a purposively selected manufacturing firm, with a total population of 1052 and which had embarked on an extensive change management programme, culminating in crisis of conflicts. Using an appropriate statistical formula for sample selection, stratified random sampling technique was employed to select 263 participants, thus, restricting the sample size to $25 \%$ of the total workforce in the organization. The basic criteria for inclusion in the sample were job rank and organizational tenure of not below 5years. Participants were categorized into two non-overlapping cadres of managerial and non-managerial employees. The company register was used as the sampling frame.

\subsection{Method of Data Collection}

Structured questionnaire was the main instrument used for data collection. Out of the 263 copies of the questionnaire self administered by the researcher, 250 copies were retrieved and fit for analysis, with a response rate of $95 \%$. The questionnaire was designed following standard guidelines for questionnaire design (Sekaran, 2003). The first part of the questionnaire sought for the biographical details of the respondents, while the second part comprised 30 items-questions to be answered in Likert scale format, which was used to measure pertinent constructs (both the independent and dependent variables of the study). Each item of the construct used was presented with five alternative responses from strongly disagree to strongly agree with numerical value $1-5$. The questionnaire survey followed all the required ethical considerations.

\subsection{Validity and Reliability}

The validation of the questionnaire was ensured through Test and $\mathrm{Re}$ - Test method with 25 employees of a related manufacturing firm. Using Cronbach alpha at 0.05 level, the reliability of co-efficient of the variables ranged from 0.786 to 0.885 reflecting appropriate adequacy and adjudging the questionnaire as valid and reliable.

\subsection{Method of Data Analysis}

The data collected were coded and analyzed using descriptive statistics (frequency and percentage counts, mean and standard deviation and inferential statistics using Spearman Correlation Coefficient and Shapiro-Wilk test. The Shapiro -Wilk test was undertaken to determine the normality of data. The results indicated that the significance level is not above 0.05 in all distributions and is not less than 0.05 with respect to other variables. Based on this outcome, Spearman correlation matrix was used for the test of hypotheses, since it does not require any particular requirement for the distribution of variables.

\section{Results of Findings}

\subsection{Biographical Details}

Findings on the biographical details of the respondents show a mean age of 32.5years with standard deviation of 6.1 years. The gender distribution of respondents reveal a disproportionate representation, where male respondents accounted for $67.1 \%$, while female contributed $32.9 \%$ in the research study. This represents a ratio of over 2.1 across the gender group skewed in favour of male respondents. These findings are connected to the low female participation in the industrial labour market as confirmed by earlier findings that majority of employees in the manufacturing industry in Nigeria are males (FITC, 2011). On marital status, $77.3 \%$ of the respondents were married while the remaining $(22.7 \%)$ of the respondents were single. Findings also show that a significant number of the respondents possessed polytechnic diploma and above. Their job rank indicated that $67.2 \%$ of the respondents were in the non managerial cadre, while the rest $(32.8 \%)$ were managerial employees. The mean organizational tenure of the respondents is 9.5 years with standard deviation of 3.5 years. These findings attested to the maturity, educational status and job rank of the participants, majority of whom are non - managerial personnel. 


\subsection{Causative Factors of Workplace Conflict}

Information was obtained from respondents by asking them the causal factors of workplace conflict in the organization. Data presented in Table 1 show means and standard deviations analysis of the causative factors: mean scores of $4.5(\mathrm{sd}=1.18)$ for conscious of workers, $4.3(\mathrm{sd}=1.20)$ for inequitable treatment, $3.75(\mathrm{sd}=1.21)$ for non - consultation with employees on key issues affecting them, $3.35(\mathrm{sd}=1.35)$ for cumbersome grievance and dispute procedure, $3.24(\mathrm{sd}=1.36)$ for nature of work activities and $3.05(\mathrm{sd}=1.38)$ for differences in perception. More than one-third, that is (34\%) of the respondents rated consciousness of workers as creating the greatest source of conflict, followed by inequitable treatment $(20 \%)$, non-consultation with employees $(18 \%)$ cumbersome of grievance and dispute procedure (15\%), nature of work activities $(8 \%)$ and differences in perception $(5 \%)$.

Table 1. Means and standard deviation of causal factors of workplace conflicts

\begin{tabular}{lccccc}
\hline \multicolumn{1}{c}{ Variables } & $\begin{array}{c}\text { Sample } \\
\text { Size }\end{array}$ & Minimum & Maximum & $\begin{array}{c}\text { Mean } \\
\text { Standard } \\
\text { Deviation }\end{array}$ \\
\hline Consciousness of workers & 250 & 1 & 5 & 4.5 & 1.18 \\
\hline Inequitable treatment & 250 & 1 & 5 & 4.3 & 1.20 \\
\hline $\begin{array}{l}\text { Non - consultation with employees on key } \\
\text { issues affecting them }\end{array}$ & 250 & 1 & 5 & 3.75 & 1.21 \\
\hline Cumbersome grievance an dispute procedure & 250 & 1 & 5 & 3.35 & 1.35 \\
\hline Nature of work activities & 250 & 1 & 5 & 3.24 & 1.36 \\
\hline Differences in perception & 250 & 1 & 5 & 3.05 & 1.38 \\
\hline Source: Field & & & & & \\
\hline
\end{tabular}

Source: Field survey, 2014

\subsection{Types of Conflict Prevalent in the Organization}

Data presented in Table 2 indicate the types of conflict that were common in the organization. On the whole, union management conflict has the highest mean score (4.51) on a Likert scale of $1-5$ numeric values, thereby presenting this conflict as the most predominant in the organization. By contrast, personal conflict has the lowest mean score (2.50) and the least rife type of conflict in the establishment.

Table 2. Means and standard deviations of prevalent types of conflict in the organization

\begin{tabular}{lccccc}
\hline \multicolumn{1}{c}{ Variables } & $\begin{array}{c}\text { Sample } \\
\text { Size }\end{array}$ & Minimum & Maximum & $\begin{array}{c}\text { Mean } \\
\text { Standard } \\
\text { Deviation }\end{array}$ \\
\hline Union - management conflict & 250 & 1 & 5 & 4.51 & 1.20 \\
\hline Procedural conflict & 250 & 1 & 5 & 3.75 & 1.22 \\
\hline Job task-related conflict & 250 & 1 & 5 & 3.50 & 1.36 \\
\hline Interpersonal conflict & 250 & 1 & 5 & 3.02 & 1.38 \\
\hline Personal conflict & 250 & 1 & 5 & 2.50 & 1.42 \\
\hline
\end{tabular}

Source: Field survey, 2014

\subsection{Conflict Management Strategies Adopted by the Organization}

Data presented in Table 3 reveal collective bargaining with mean score of $4.4(\mathrm{sd}=1.21)$, compromise, 3.75 ( $\mathrm{sd}=1.27)$ and accommodation 3.65 ( $\mathrm{sd}=1.28)$, as the integrative conflict management strategies being used in the manufacturing firm. Other methods of managing conflict rated below 2.5 include confrontation with mean score value of $1.64(\mathrm{sd}=0.96)$, competition, $1.62(\mathrm{sd}=0.72)$ and avoidance $1.50(\mathrm{sd}=0.82)$. Respondents were also asked to rate the importance of each indicator using 5-point. Likert scale with end point labelled least important with numeric value (1) and most extremely important (5). Results indicate collective bargaining as the most extremely important and most productive conflict management strategy. Worthy of note is that the organization hardly uses the palliative methods of avoidance, competition and confrontation which are non-integrative collaborative are regarded as conflict management strategies. 
Table 3. Means and standard deviation of conflict management strategies adopted by the organization

\begin{tabular}{lccccc}
\hline \multicolumn{1}{c}{ Conflict Management Strategies } & $\begin{array}{c}\text { Sample } \\
\text { Size }\end{array}$ & Minimum & Maximum & Mean & $\begin{array}{c}\text { Standard } \\
\text { Deviation }\end{array}$ \\
\hline Collective Bargaining & 250 & 1 & 5 & 4.4 & 1.21 \\
\hline Compromise & 250 & 1 & 5 & 3.7 & 1.27 \\
\hline Accommodation & 250 & 1 & 5 & 3.65 & 1.28 \\
\hline Confrontation & 250 & 1 & 5 & 1.64 & 0.96 \\
\hline Competition & 250 & 1 & 5 & 1.62 & 0.72 \\
\hline Avoidance & 250 & 1 & 5 & 1.50 & 0.82 \\
\hline
\end{tabular}

Source: Field survey, 2014

\subsection{Test of Hypotheses}

Hypothesis 1: There is a significant relationship between workplace conflict management and organizational performance

Spearman correlation was used to test the hypothesis of the link between workplace conflict management and organizational performance. Data presented in Table 4 show that there is a significant statistically determinate effect between workplace conflict management and organizational performance with the coefficient of $33.5 \%$ at the significance level of 0.01 . The result reveals that the null hypothesis as postulated for the study was rejected, while the alternative hypothesis was accepted. Thus, a statistically significant relationship between workplace conflict management and organizational performance was found.

Table 4. Matrix of correlation between workplace conflict management and organizational performance

\begin{tabular}{ccl}
\hline Workplace Conflict Management & Organizational Performance & Variables \\
\hline & 1 & Organizational performance \\
\hline 1 & $0.335^{* *}$ & \\
\hline & 0.001 & Workplace conflict Management \\
\hline
\end{tabular}

Source: Field survey, 2014.

Hypotheses 2-7: There is a significant relationship between workplace conflict management strategies (collective bargaining, compromise, accommodation, confrontation, competition and avoidance) and organizational performance.

In order to test hypotheses (2-7), Spearman correlation method was used. Data in Table 5, indicate that collective bargaining strategy has a positive correlation with organizational performance at the confidence level of 0.001 and thus the hypothesis about the collective bargaining strategy was accepted. Relatedly, both compromise and accommodation strategies have positive and significant correlation with organizational performance at the confidence level of 0.05 . Thus, the hypotheses were also accepted that integrative conflict management strategies significantly enhanced organizational performance in the organization. The non-integrative strategies of confrontation, competition and avoidance did not have any significant correlations with organizational performance, thus, the relationship were rejected. 
Table 5. Correlation matrix of workplace conflict management strategies and organizational performance

\begin{tabular}{llcccccc}
\hline Variables & \multicolumn{1}{c}{ CB } & COM & ACC & CON & COMP & AV & OP \\
\hline CB & $0.675^{* *}$ & & & & & & \\
& 0.000 & & & & & & \\
\hline COM & $0.481^{*}$ & $0.450^{*}$ & & & & & \\
& 0.002 & 0.003 & & & & & \\
\hline ACC & $0.406^{*}$ & $0.316^{*}$ & $0.397^{* *}$ & & & & \\
& $0.003^{*}$ & 0.003 & $0.002^{*}$ & & & & \\
\hline CON & 0.110 & 0.102 & 0.358 & 0.196 & & & \\
& 0.235 & 0.257 & 0.023 & 0.012 & & & \\
\hline COMP & 0.102 & 0.112 & 0.395 & 0.343 & 0.342 & & \\
& 0.256 & 0.220 & $0 . .22$ & 0.111 & 0.026 & & \\
\hline AV & 0.111 & 0.023 & 0.361 & 0.380 & 0.293 & 0.097 & \\
& 0.234 & 0.012 & 0.034 & 0.095 & 0.016 & 0.294 & \\
\hline OP & $0.546^{* *}$ & $0.408^{*}$ & $0.340^{*}$ & 0.086 & 0.026 & 0.096 & 1.002 \\
& 0.000 & 0.003 & 0.003 & 0.341 & 0.022 & 0.291 & 0.221 \\
\hline
\end{tabular}

** Significance at $\mathrm{p}<0.01$ level ( 2 tailed $)$

* Significance at $\mathrm{P}<0.01$ level ( 2 tailed)

$\mathrm{CB}=$ Collective Bargaining Strategy

$\mathrm{COM}=$ Compromise Strategy

COMP $=$ Competition Strategy

$\mathrm{ACC}=$ Accommodation Strategy

$\mathrm{AV}=$ Avoidance Strategy

$\mathrm{OP}=$ Organizational Performance

\subsubsection{Regression Analysis}

Regression analysis was employed to predict the most effective of the conflict management strategies on organizational performance. The results of the findings based on independent variables of (collective bargaining, compromise, accommodation, confrontation, competition and avoidance strategies are shown in Table 6 .

The overall model fit for regression equation was determined by F-statistics. The model reveals positive and statistically significant relationship $(\mathrm{F}=12.735 \mathrm{P}<0.001)$. The independent variables accounted for $51.2 \%\left(\mathrm{R}^{2}=\right.$ 0.512) of variance in the dependent variable of organizational performance. Collective bargaining strategies with highest beta -coefficient (0.480) is the most effective, with higher significant impact of the integrative conflict management strategies followed by compromise, with beta coefficient $(0.450)$, accommodation (Beta $=0.421)$, confrontation $($ Beta $=0.216)$, competition $($ Beta $=0.214)$ and Avoidance $($ Beta $=0.210)$ respectively.

Table 6. Regression analysis of the most effective conflict management strategies on organizational performance

\begin{tabular}{lcccc}
\hline \multicolumn{1}{c}{ Indicators } & $\begin{array}{c}\text { Proposed } \\
\text { Effects }\end{array}$ & $\begin{array}{c}\text { Beta } \\
\text { Coefficients }\end{array}$ & $\begin{array}{c}\text { Observed } \\
\text { t-value }\end{array}$ & $\begin{array}{c}\text { Sig. } \\
\text { Level }\end{array}$ \\
\hline Collective Bargaining & $+\mathrm{ve}$ & .480 & 5.575 & $000^{*}$ \\
\hline Compromise & $+\mathrm{ve}$ & .445 & 5.302 & $000^{*}$ \\
\hline Accommodation & $+\mathrm{ve}$ & .421 & 5.102 & $000^{*}$ \\
\hline Confrontation & $-\mathrm{ve}$ & .216 & 2.198 & 0.046 \\
\hline Competition & $-\mathrm{ve}$ & .214 & 2.393 & 0.111 \\
\hline Avoidance & $-\mathrm{ve}$ & .210 & 2.186 & 0.223
\end{tabular}

Significance level * $\mathrm{p}, 0.001, \mathrm{~N}=250$

Overall model 12.735, $\mathrm{p}<0.00 \mathrm{R}^{2}=0.512$, Adjusted $\mathrm{R}^{2}=0.482$ 


\section{Discussion of Findings}

This study contributes to the understanding of impact of workplace conflict management on organizational performance in a Nigerian manufacturing organization. The results of the study offered strong empirical support for the existence of a positive and statistically significant effect of conflict management on organizational performance. Copious evidence abounds in the analysis that if an organization adopts integrative conflict management strategies, organizational performance will increase. To a very large extent, the findings of this present study concur with earlier empirical studies on conflict management and organizational performance that the use of integrative strategies in conflict management yields positive results (Kazimoto, 2013; Obasan, 2011; and Henry, 2009).

Review of literature identified diverse causal factors of workplace conflict as consciousness of workers, inequitable treatment, cumbersome grievance and dispute procedures and difference in perception amongst others (Obi, 2012; and Obasan, 2011). The results of this present study are consistent and in harmony with those in literature and further replicate previous empirical studies of Uchedu, Anijaobi and Odigwe (2013); Tseveendorj (2008) and Ikeda, Veludo and Campomar (2005) on causative factors of workplace conflict. As such, empirical evidence from the study did confirm that conflict in work relations could arise over multiple factors of organizational experiences based on economic and goal incompatibility orientations in the workplace.

Furthermore, the empirical study has shown that there are dissimilarities in the types of conflict in work-relations. Study findings indicate that job-task related conflict, procedural conflict, interpersonal conflict and union-management conflict are the common types in existence in the organization. This result however is significant in providing evidence on consensus rating of union-management conflict as the most prevalent type in the organization. The finding buttressed the views of Fajana and Shadare (2012) that in employment relationship, the interests of employers represented by management and employees represented by the union have often been diametrically opposed in work-organizations. This has historically been the major cause of conflict in unionized organizations, not only in Nigeria, but also in developed economies.

The results of the present study were aligned with those of Comboh (2014) and Mugal and Khan (2013) on conflict management and organization performance. What has emanated within the context of this present study deviated from Comboh's study that all types of industrial conflicts are negatively associated with employees and organizational performance. Empirical evidence from this study has suggested a positive link between conflict management strategies of collective bargaining, compromise and accommodation and organizational performance. This position was reinforced by the previous findings of Mugal and Khan (2013) as re-affirmed by the study hypotheses. Specifically, regression analysis indicated that collective bargaining strategy displayed the highest significant positive correlation with organizational performance. Non-integrative conflict management strategies (competition, domination and avoidance) showed a negative statistically determinate effect on organizational performance. Thus, the findings corroborated with the assertions of Mba (2013) and Henry (2009) that managers prefer the use of integrative management strategies which are relatively useful in minimizing the incidence of disruptive conflict and having positive impact on corporate productivity and organizational performance. With integrative conflict management strategy, there is often high confidence and trust in one another among organizational members, loyalty to the work group and to the organization in the achievement of corporate performance.

\section{Conclusion and Recommendations}

The study investigated the impact of conflict management on organizational performance in a manufacturing organization in a reforming and developing economy. Review of literature provided strong evidence of integrative conflict management strategies and their relationship with organizational performance. The present study empirically reinforced the results of previous studies with regard to the link between workplace conflict management and business performance. The study also highlighted the importance of integrative conflict management as a technique of changing from the destructive status of conflict situation to constructive handling of conflicts in the enhancement of organizational performance in the workplace.

However, the present study is not without some limitations as the scope of the research centered mainly on the manufacturing industry. The restrictive nature of the study to a single manufacturing firm and the small size of the sample used, pose a threat to the generalizability of the findings and may make them not applicable to other sectoral industries. Despite these limitations, the study has made an important contribution to the understanding of the relationship between workplace conflict management and organizational performance in the Nigerian manufacturing industry. 
Based on the findings of the study, the following recommendations have been found necessary. Management in the workplace must try to adopt an inclusive and collaborative strategies in conflict management and at the same time strive to involve union - leadership or employee representative in vital decisions that affect the workforce. Both management and employees must resolve to work together amicably by formulating potent strategies and sustaining acceptable policies as effective machinery for managing conflict on continuous basis in organizations. Credible channels of communication and open discussions of conflict in work relations must be encouraged with an attempt to avoid confrontation, competition and domination as conflict management strategies. Mutual survival and continued sustenance of optimum organizational performance are both the goal and basis for the existence of employees and employers in the industrial work-setting.

\section{References}

Adebisi, M. (2004). Industrial Conflict and Trade Unionism in Nigeria. Journal of Department of Business Administration, University of Ilorin, 14(1), 11-17.

Adomi, E., \& Anie, S. (2005). Conflict Management in Nigerian University Libraries. Journal of Library Management, 27(8), 520-530. http://dx.doi.org/10.1108/01435120610686098

Ajala, M., \& Oghenekohwo, J. (2002, Jan-Dec.). Appraisal of Public Policy on Conflict Resolution for harmonious industrial Relations Practise in Nigeria. Journal of African Labour Studies, 5(1 \& 2), 78-87.

Akanji, I. (2005). Perspectives in Workplace Conflict Management and New Approaches for the Twenty first Century. In Albert I.O (Ed.), Perspective on Peace and Conflict in Africa: Essays in Honour of Gen. Abdusalam Abubakar, Ibadan: John Arches Publishers.

Albert, I. (2001). Introduction to Thirty Party Intervention in Community Conflict. Ibadan: John Arches Publisher.

Azamosa O. (2004). Industrial Conflict in Nigerian Universities. The case of the Academic staff union of the university teachers' strike of December 2002 - July 2003. Dept. of Sociology Anthropology and Applied social sciences, British University. Retrieved from http://ww.ajbms.com/articlepdf010506pdf

Comboh, M. (2014). Examining Conflicts in Industrial Relations and Collective Bargaining Context and its Impact on Workers and Organizational Performance. Academy of Contemporary Research Journal, 3(1), 14-25.

Fajana, S., \& Shadare, O. (2012, January). Workplace Relations, Social Dialogue and Political Milieu in Nigeria. International Journal of Business Administration, 3(1), 75-83. http://dx.doi.org/10.5430/ijba.v3n1p75

Financial Institution Training Centre. (2011). Gender Relations in the Workplace: The Nigeria Experience-Lagos, Nigeria. FITC Publication.

Ford, J. (2007). Organisational Conflict Management, What" a System? Retrieved from www.mediate.com/pfriendly.cfmid-250

Henry, O. (2009). Organisational Conflict and its Effects on Organizational Performance. Research Journal of Business Management, 2(1), 16-24. http://dx.doi.org/10.3923/rjbm.2009.16.24

Hotepo, O., Asokere, A. Abdul-Azeez, I., \& Ajemuigbolohun, S. (2010). Empirical Study of the Effect of Conflict on Organisational Performance in Nigeria. Business and Economic Journal, 15, 1.

Ikeda, A., Veludo, O., \& Campomar, M. (2005). Organisational Conflicts Perceived by Marketing Executives. Electronic Journal of Business and Organisational Studies, 10(1), 22-28.

Kazimoto, P. (2013). Analysis of Conflict Management and Leadership for Organizational Change. International Journal of Research in Social Sciences, 3(1), 16-25.

Mba, O. (2013). Conflict Management and Employee Performance in Julius Berger Nigeria Plc. Bonny Island. International Journal of Academic Research in Management, 2(4), 125-139.

Mugal, M., \& Khan, M. (2013, December). Impact of Conflict and Conflict Management on Organizational Performance. International Journal of Modern Business - Issues on Global Market, 1(3), 1-19.

Obasan, K. (2011, August). Impact of Conflict Management on Corporate Productivity: An Evaluative Study. Australian Journal of Business and Management Research, 1(5), 44-49.

Obi, R. (2012). Stress and Conflict in Organisation. In Ogunbameru O.A. (Ed.), Industrial Sociology. Ibadan, Spectrum Books Ltd.

Ogunbameru, O. (2006). Organizational Dynamics, Ibadan. Spectrum Book Publishers. 
Osad, O., \& Osas, V. (2013). Harmonious Industrial Relations as a Panacea for Ailing Enterprises in Nigeria. Journal of Asian Scientific Research, 3(3), 229-246.

Rahim, M. (2002). Towards a Theory of Managing Organizational Conflict. The International Journal of Conflict Management, 13(3), 206-235. http://dx.doi.org/10.1108/eb022874

Sekaran L. (2003). Research Method for Business-A Skill Building Approach. New York, USA: John Wiley and Sons Inc.

Thomas, K. (1976). Conflict and Conflict Management. A Handbook of Industrial and Organizational Psychology. New York, USA: John Wiley and Son. Inc.

Tsevendorj, O. (2008). Conflict Resolution: A basis for Effective Conflict Management of Banks in Baquio City. Thesis submitted to St. Louis University, Baquio City, Philllipines.

Uchendu, C., Anijaobi, F., \& Odigwe, F. (2013). Conflict Management and Organisational Performance in Secondary Schools in Cross Rivers State. Nigeria Research Journal in Organisational Psychology and Educational Studies, 2(2), 67-71.

Vigil-King, D. (2000). Team Conflict, Integrative Conflict Management Strategies and Team Effectiveness. Unpublished Doctoral Dissertation University of Tennesse, Knoxville. 